\title{
Phytoplankton status of Mahakali River, Nepal
}

\author{
Vinod Kumar Mahaseth \\ Department of Zoology, M.M.A.M. Campus, T.U., Biratnagar, Nepal \\ E-mail:vkmahaseth@gmail.com
}

\begin{abstract}
Distribution of phytoplankton in Mahakali river was studied during 20032005. During the investigation a total of 31 genera belonging to 5 classes were identified. Chlorophyceae was dominant being represented by 15 genera, followed by Bacillariophyceae ( 9 genera), Cyanophyceae (5 genera), and 1 genus each of Dinophyceae and Xanthophyceae. The peak of Chlorophyceae was obtained in the month of April (465 units/l) during first year while in second year it was observed in the month of February (505 units/l). The maximum of Cyanophyceae was observed in the month of May (460 units/l) and March (216 units/l) during first and second year, respectively. Bacillariophyceae showed its maximum contribution during May (622 units/l) in first year and in March (600 units/l) in second year. The maximum density of phytoplankton was found during pre monsoon and minimum in early period of post monsoon (Sep.) and late period of monsoon. The density of phytoplankton increased from post monsoon (Oct.), whereas in rainy season, it was least due to dilution factor.
\end{abstract}

Key words: Diatoms, chlorophyceae, cyanophyceae, Microcystis, monsoon.

\section{Introduction}

Phytoplankton forms the base of food chain in most of the aquatic ecosystems, thus playing a vital role in fisheries. The productivity of a water body is characterized by the presence of living organisms in the natural environment. Among the biotic components of an aquatic ecosystem, phytoplankton community plays a significant role in the productivity of the water body. Some of the prominent contributions on the various aspects of phytoplankton community analysis in freshwater bodies have been made by George (1966), Sarkar and Rai (1964), Munawar (1972), Abbas (1979), Sharma et al. (1982), Singh and Sharma (1998), Murugesan et al. (2003), Srivastava and Prakash (2003), Shrivastava (2005), Gurung et al. (2006), Tiwari and Chauhan (2006), Veereshkumar and Homani (2006), Tiwari and Shukla (2007), Sinthikumar and Sivakumar (2008), Singh and Singh (2008), Mukherjee et al. (2010), Kushwaha (2012). But the information regarding plankton of Mahakali river is very limited.

\section{Study Site}

The present study was conducted at the Chandani and Dodhara (Fig. 1), the V.D.C of Kanchanpur district near the bank of Mahakali river. The study area lies between longitude $80^{\circ} 25^{\prime} \mathrm{E}$ and latitude $28^{\circ} 35^{\prime} \mathrm{N}$. It is situated at $176 \mathrm{~m}$ altitude. In the present study $12 \mathrm{Km}$ of the river was investigated. Four sampling stations were selected for collection of water samples. Water samples from all the four stations were collected from three different depths. 


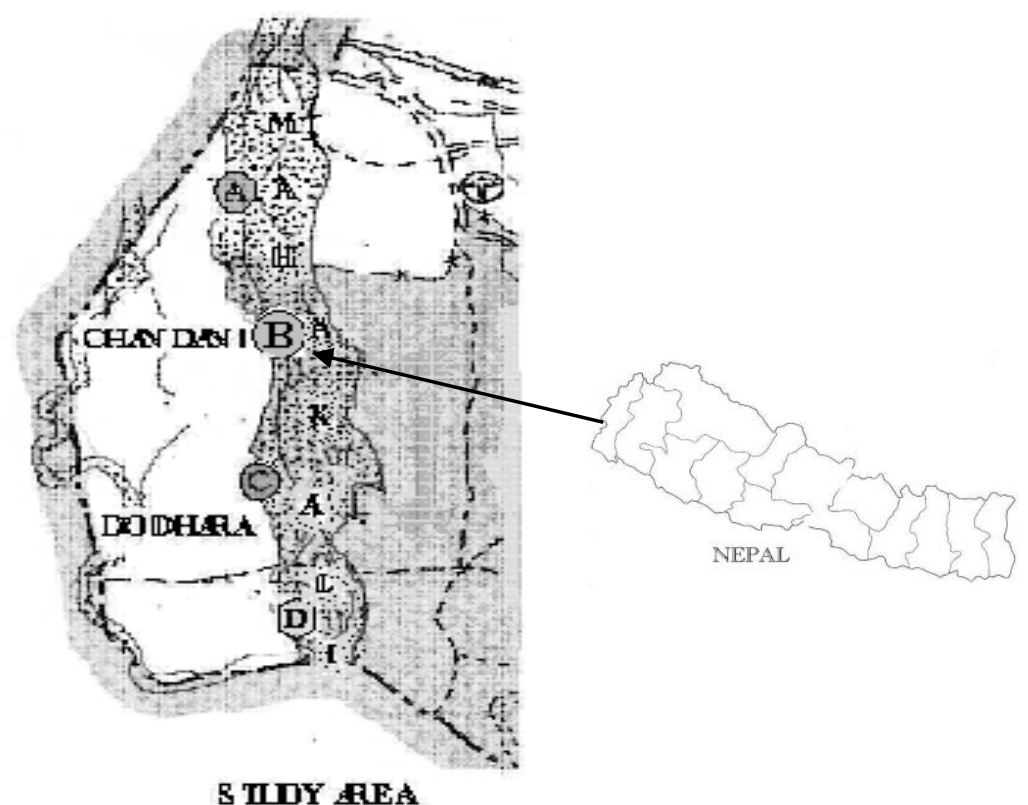

Figure 1. Chandani and Dodhara study area.

\section{Materials and Methods}

The samples for the qualitative and quantitative estimation of phytoplankton were collected from the different stations of the study area, during an interval of 15 days at 8.30 to 9.30 a.m. and all the samples were mixed together and formed compound sample for study. For the qualitative estimations, known volume of surface water was filtered through Whatman No.44 filter paper on the same day of collection. The filter paper was washed thoroughly with a wash bottle and the plankton was collected in a tube, which was later centrifuged, and the sample was concentrated up to $5 \mathrm{ml}$.

Census of phytoplankton population was done with an improved bright line haemocytometer. Phytoplankton population was counted in all the 9 chambers of the haemocytometer. The calculation of the phytoplankton density was done by the following way.

The haemocytometer slide is divided into two separate fields. Each field is a grid measuring $3 \times 3 \mathrm{~mm}$. Since, there is $1 / 10 \mathrm{~mm}$ space between the cover slip and the slide, so the volume contained over the grid is $3 \mathrm{~mm} \times 3 \mathrm{~mm} \times 0.1 \mathrm{~mm}=0.9 \mathrm{~mm}^{3}$.

Thus No. of cells/ $1=\frac{\text { No. of cells }}{0.9 \mathrm{~mm}^{3}} \times \frac{1000 \mathrm{~mm}^{3}}{1 \mathrm{~cm}^{3}} \times \frac{1000 \mathrm{~cm}^{3}}{11}$

The final values were obtained by dividing the above values by the concentration factor of the initial sample. The phytoplankton were identified by the help of Edmondson (1959) and Fitter and Manuel (1986). 


\section{Results and Discussion}

Phytoplankton of the river system consisted of 31 genera belonging to three major classes, Chlorophyceae, Cyanophyceae and Bacillariophyceae. On the quality basis Chlorophyceae was dominant being represented by 15 genera, followed Bacillariophyceae (9 genera), Cyanophyceae (5 genera), 1 genus each of Dinophyceae and Xanthophyceae (Table 1).

Table 1. List of phytoplankton species collected from Mahakali river during $2003-2005$.

\begin{tabular}{|c|c|c|c|c|}
\hline \multirow[b]{2}{*}{ SN } & \multicolumn{4}{|c|}{ Phytoplanktons } \\
\hline & Chlorophyceae & Bacillariophyceae & Cyanophyceae & Dinophyceae Xanthophyceae \\
\hline 1 & Chlorella $\mathrm{Sp}$ & Navicula Sp. & Microcystis $\mathrm{Sp}$. & Ceratium Sp. Tribonema Sp. \\
\hline 2 & Chlamydomonas $\mathrm{Sp}$ & Diatoma Sp. & Spirulina $\mathrm{Sp}$. & \\
\hline 3 & Spirogyra Sp & Synedra Sp. & Gomphosphaeria Sp. & \\
\hline 4 & Cladophora $\mathrm{Sp}$ & Cymbella Sp. & Oscillatoria Sp. & \\
\hline 5 & Coelestrum Sp. & Gomphonema Sp. & Merismopedia Sp. & \\
\hline 6 & Gonatozygon Sp. & Fragilaria $\mathrm{Sp}$. & & \\
\hline 7 & Scenedesmus Sp. & Gyrosigma Sp. & & \\
\hline 8 & Ankistrodesmus Sp. & Asterionella Sp. & & \\
\hline 9 & Mougeotia Sp. & Tabellaria Sp. & & \\
\hline 10 & Pediastrum Sp. & & & \\
\hline 11 & Closteridium Sp. & & & \\
\hline 12 & Closterium Sp. & & & \\
\hline 13 & Actinastrum Sp. & & & \\
\hline 14 & Desmidium Sp. & & & \\
\hline 15 & Cosmarium Sp. & & & \\
\hline & 15 & 9 & 5 & 1 \\
\hline
\end{tabular}

Chlorophyceae was the dominant group due to the presence of Chlorella almost throughout the year. Chlamydomonas and Spirogyra were two other dominant members of Chlorophyceae (Tables 2 \& 3). Bacillariophyceae was the second dominant group. Diatoma was mainly responsible for the dominance of this group which was abundant throughout the year (Tables 2 \& 3). Cyanophyceae was the third dominant phytoplankton group. The dominant member of Cyanophyceae was Microcystis which was found throughout the year, followed by Spirulina (Tables $2 \& 3$ ). The density of phytoplankton ranged between $73-1566$ units/l, minimum value being observed in monsoon and maximum in pre-monsoon (summer) (Tables $2 \& 3$ ).

The occurrence of Dinophyceae and Xanthophyceae were not remarkable. The phytoplankton taxa were most abundant in pre-monsoon and least in winter season. The density of the total phytoplankton ranged between 73 units/l (Sep.) to 1566 units/l (May) and 102 units/l (Aug.) to 1226 units/l (March) during the first and second year, respectively (Table 4).

Green algae (Chlorophyceae) were maximum, 465 units/l (April) and 505 units/l (February) during first and second year, respectively (Table 4). Cyanophyceae (Blue green algae) were maximum, 460 units/l in May and 216 units/l in March during first and second year, respectively (Table 4). Bacillariophyceae (Diatoms) were maximum, 622 units/l in May and 600 units/l in March during first and second year, respectively. Dinophyceae and Xanthophyceae were rare during the entire study period (Table 4). Chlorophyceae were minimum 40 units/l in September and 12 units/l in August during first and second year, respectively. Cyanophyceae were 
minimum 11 units/l in September and 17 units/l in August during following years, while Bacillariophyceae were minimum 22 units/l and 50 units/l in September during both years.

Table 2. Quantitative analysis of phytoplankton of Mahakali river during 2003-2004

\begin{tabular}{|c|c|c|c|c|c|c|c|c|c|c|c|c|c|}
\hline \multirow{2}{*}{\multicolumn{14}{|c|}{ Sep. Oct. Nov. Dec. Jan. Feb. Mar. Apr. May Jun. Jul. Aug. Total }} \\
\hline & & & & & & & & & & & & & \\
\hline \multicolumn{14}{|c|}{$\begin{array}{lllll}89 & 83 & 50 & 17 & 468\end{array}$} \\
\hline Chlamydomonas Sp. & 11 & 6 & 17 & 33 & 39 & 50 & - & 94 & 122 & - & - & - & 372 \\
\hline Spirogyra Sp. & - & - & 33 & 28 & 44 & 105 & 155 & 144 & 117 & 100 & 72 & 33 & 831 \\
\hline Cladophora Sp. & - & - & - & - & - & - & 78 & 83 & 128 & - & 89 & 28 & 406 \\
\hline Coelestrum Sp. & - & - & - & - & - & - & - & - & - & 17 & - & - & 17 \\
\hline Gonatozygon Sp. & - & 28 & - & - & - & - & - & 72 & - & 39 & - & 28 & 167 \\
\hline Scenedesmus Sp. & 6 & - & - & - & - & - & - & - & & - & 17 & - & 23 \\
\hline Ankistrodesmus Sp. & - & - & - & - & - & - & - & - & - & - & - & 17 & 17 \\
\hline Mougeotia Sp. & 6 & 11 & 22 & 17 & 33 & - & - & - & - & - & - & - & 89 \\
\hline Pediastrum Sp. & 11 & 11 & 17 & - & 22 & - & - & - & - & - & - & - & 61 \\
\hline Closteridium Sp. & - & - & - & - & - & - & - & - & & - & - & - & - \\
\hline Closterium Sp. & - & - & - & - & - & - & - & - & - & - & - & - & - \\
\hline Actinastrum Sp. & - & - & - & - & - & - & - & - & - & - & - & - & - \\
\hline Desmidium Sp. & - & - & - & - & - & - & . & - & - & - & - & - & - \\
\hline Cosmarium Sp. & - & - & - & - & - & - & - & - & - & - & - & - & - \\
\hline \multicolumn{14}{|l|}{ Cyanophyceae } \\
\hline Microcystis $\mathrm{Sp}$. & 11 & 17 & 33 & 44 & 72 & 89 & 94 & 105 & 144 & 111 & 67 & 28 & 815 \\
\hline Spirulina Sp. & - & 22 & 28 & 39 & - & 44 & 72 & 117 & 149 & 78 & 56 & 22 & 627 \\
\hline Gomphosphaeria Sp. & - & - & - & - & - & - & - & - & 111 & - & - & - & 111 \\
\hline Oscillatoria Sp. & - & 22 & - & - & - & - & - & - & 56 & - & - & - & 78 \\
\hline Merismopedia $\mathrm{Sp}$. & - & - & - & - & - & - & - & - & - & - & - & 11 & 11 \\
\hline \multicolumn{14}{|l|}{ Bacillariophyceae } \\
\hline Navicula Sp. & - & - & - & - & - & - & - & 22 & - & - & - & - & 22 \\
\hline Diaton & 22 & 28 & 39 & 56 & 72 & 78 & 100 & 178 & 222 & 155 & 56 & 28 & 1034 \\
\hline Syn & - & - & 33 & 44 & 50 & 72 & 94 & 111 & 144 & 105 & 28 & 17 & 698 \\
\hline Cymbella Sp. & - & - & - & - & - & - & - & 56 & - & - & - & - & 56 \\
\hline Gomphonema Sp. & - & - & - & - & - & - & - & - & 89 & - & - & - & 89 \\
\hline Fragilaria Sp. & - & - & - & - & - & - & 28 & - & 78 & 39 & - & - & 145 \\
\hline Gyrosigma Sp. & - & - & - & - & - & & 17 & - & 89 & - & 22 & - & 128 \\
\hline Asterionella Sp. & - & - & - & - & - & - & - & - & - & - & - & - & \\
\hline Tabellaria Sp. & - & - & - & 17 & - & - & - & - & - & - & - & - & 17 \\
\hline \multicolumn{14}{|l|}{ Dinophyceae } \\
\hline Ceratium $\mathrm{Sp}$. & - & 17 & _ & - & - & - & - & 22 & 28 & - & - & - & 67 \\
\hline \multicolumn{14}{|l|}{ Xanthophyceae } \\
\hline Tribonema Sp. & - & - & - & - & - & - & - & - & - & - & 17 & - & 17 \\
\hline Total & 73 & 168 & 233 & 295 & 349 & 482 & 694 & 107 & 56 & & 474 & 229 & 6366 \\
\hline
\end{tabular}

The number of genera varied throughout the year. The maximum number of genera (14) was recorded in May 2004 and the minimum (7) in Sep. 03, Feb. 04 and Jan. 05 during the entire study period (Table 5).

During the present study, the phytoplankton density varied from 73 units/l in September to 1566 units/l in May and 102 units/l in August to 1226 units/l in March during the first and second year of investigations, respectively. The maximum density of phytoplankton was found during pre- 
monsoon (March and May) and lowest during monsoon (August) and post-monsoon (September). The density of phytoplankton increased from post-monsoon (October). Increase in phytoplankton population from post-monsoon (October) is a characteristic feature of other rivers.

Table 3. Quantitative analysis of phytoplankton of Mahakali river during 2004 - 2005

\begin{tabular}{|c|c|c|c|c|c|c|c|c|c|c|c|c|c|}
\hline \multirow{2}{*}{$\begin{array}{l}\text { Phytoplankton } \\
\text { Chlorophyceae }\end{array}$} & \multicolumn{13}{|c|}{ Sep. Oct. Nov. Dec. Jan. Feb. Mar. Apr. May Jun. Jul. Aug. Total } \\
\hline & & & & & & & & & & & & & \\
\hline Chlorella Sp. & 17 & 33 & 50 & 72 & 83 & 105 & 144 & - & 111 & 61 & 33 & 6 & 715 \\
\hline Chlamydomonas Sp. & 6 & - & 11 & 17 & - & 111 & 122 & 117 & 100 & - & - & - & 484 \\
\hline Spirogyra Sp. & - & - & 50 & 67 & 94 & 122 & 144 & 105 & 28 & - & - & - & 610 \\
\hline Cladophora Sp. & - & - & - & - & - & - & - & - & - & 44 & 28 & - & 72 \\
\hline Coelestrum Sp. & - & - & - & - & - & - & - & - & - & - & - & - & \\
\hline Gonatozygon Sp. & - & 33 & - & - & - & 56 & - & - & - & 39 & 17 & 6 & 151 \\
\hline Scenedesmus Sp. & 22 & - & - & - & - & - & - & & - & - & - & - & 22 \\
\hline Ankistrodesmus Sp. & - & - & - & - & - & - & - & - & - & - & - & - & \\
\hline Mougeotia Sp. & 28 & 33 & - & - & 94 & 111 & - & - & - & - & - & - & 266 \\
\hline Pediastrum Sp. & - & 28 & 39 & 50 & 56 & - & - & - & - & - & - & - & 173 \\
\hline Closteridium Sp. & 11 & - & - & - & - & - & - & - & - & - & - & - & 11 \\
\hline Closterium Sp. & 6 & - & - & - & - & - & - & - & - & - & - & - & 6 \\
\hline Actinastrum Sp. & - & - & - & - & - & - & - & 28 & - & - & - & - & 28 \\
\hline Desmidium Sp. & - & - & - & - & - & - & - & - & - & 17 & - & - & 17 \\
\hline Cosmarium Sp. & - & - & - & - & - & - & - & - & 33 & - & - & - & 33 \\
\hline Cyanophyceae & & & & & & & & & & & & & \\
\hline Microcystis $\mathrm{Sp}$. & 22 & 17 & 28 & 44 & 61 & 78 & 105 & 94 & 78 & 56 & 22 & 6 & 611 \\
\hline Spirulina Sp. & - & 28 & 33 & 50 & - & 89 & 111 & - & - & 44 & 17 & 11 & 383 \\
\hline Gomphosphaeria Sp. & - & - & - & - & - & - & - & - & - & - & - & - & \\
\hline Oscillatoria Sp. & - & 22 & - & - & - & - & - & - & - & 17 & - & - & 39 \\
\hline Merismopedia Sp. & - & - & - & - & - & - & - & - & - & - & - & - & \\
\hline Bacillariophyceae & & & & & & & & & & & & & \\
\hline Navicula Sp. & - & - & - & - & - & - & - & - & - & - & 11 & - & 11 \\
\hline Diatoma Sp. & 50 & 61 & 72 & 94 & 122 & 144 & 205 & 200 & 155 & 94 & 44 & 17 & 1258 \\
\hline Synedra Sp. & - & - & 28 & 39 & 56 & - & 189 & 78 & - & - & - & 22 & 412 \\
\hline Cymbella Sp. & - & - & - & - & - & 50 & 83 & 89 & 78 & 72 & - & 17 & 389 \\
\hline Gomphonema Sp. & - & - & - & - & - & - & - & - & - & - & 28 & - & 28 \\
\hline Fragilaria Sp. & - & - & - & - & - & 44 & 39 & - & 44 & 39 & 28 & 6 & 200 \\
\hline Gyrosigma Sp. & - & - & - & - & - & - & - & - & 28 & - & - & - & 28 \\
\hline Asterionella Sp. & - & - & - & 33 & - & 28 & 56 & 61 & 67 & 56 & 44 & 11 & 356 \\
\hline Tabellaria Sp. & - & - & - & - & - & - & 28 & - & - & - & 17 & - & 45 \\
\hline$\overline{\text { Dino }}$ & & & & & & & & & & & & & \\
\hline Ceratium $\mathrm{Sp}$. & - & 11 & - & - & - & - & - & - & - & - & - & - & 11 \\
\hline
\end{tabular}

\section{Xanthophyceae}

Tribonema Sp.

Total $1622663114665669381226772 \quad 722 \quad 539289 \quad 102 \quad 6359$

During monsoon (August) and post-monsoon (September) months, the density of phytoplankton was least due to dilution factor as a result of heavy precipitation in the catchment areas of river Mahakali. During monsoon months the river was heavily flooded and highly turbid with maximum velocity. Phytoplankton suspended in river water were dislodged and flushed out by the water current. This may be the reason for the poor representation of plankton group during 
the monsoon. Similar observations have been made by Srivastava and Singh (1995) in the Ganga river.

Phytoplankton density, it's species composition and the dominance of certain species may vary from river to river, from location to location within the same river or even at the same location of a river from year to year. Sharma (1991) reported minimum density of plankton 20 units/l in August and 998 units/l in January from Bhagirathi river. Sehgal (1992) reported phytoplankton density between 13 to 11,643 units/l in 1985 and from 3 to 20,896 units/l in 1986 from the river Beas of Himachal Pradesh. Khanna et al. (1992) observed maximum number of Diatoms 4152 units/l in January and minimum 511.50 units/l in July from the Ganga river at Sapt Sarovar, Hardwar.

Table 4. Total estimated (units/l) composition of different classes of phytoplankton of Mahakali river during two years (2003-2005).

\begin{tabular}{lcccccc}
\hline Month & Chloro & Cyno & Bacillario & Dino & Xantho & Total units/l \\
\hline Sep.2003 & 40 & 11 & 22 & - & - & 73 \\
Oct. & 62 & 61 & 28 & 17 & - & 168 \\
Nov. & 100 & 61 & 72 & - & - & 233 \\
Dec. & 95 & 83 & 117 & - & - & 295 \\
Jan.2004 & 155 & 72 & 122 & - & - & 349 \\
Feb. & 199 & 133 & 150 & - & - & 482 \\
Mar. & 289 & 166 & 239 & - & - & 694 \\
Apr. & 465 & 222 & 367 & 22 & - & 1076 \\
May & 456 & 460 & 622 & 28 & - & 1566 \\
Jun. & 239 & 189 & 299 & - & - & 727 \\
Jul. & 228 & 123 & 106 & - & 17 & 474 \\
Aug. & 123 & 61 & 45 & - & - & 229 \\
Sep. & 90 & 22 & 50 & - & - & 162 \\
Oct. & 127 & 67 & 61 & 11 & - & 266 \\
Nov. & 150 & 61 & 100 & - & - & 311 \\
Dec. & 206 & 94 & 166 & - & - & 466 \\
Jan.2005 & 327 & 61 & 178 & - & - & 566 \\
Feb. & 505 & 167 & 266 & - & - & 938 \\
Mar. & 410 & 216 & 600 & - & - & 1226 \\
Apr. & 250 & 94 & 428 & - & - & 772 \\
May & 272 & 78 & 372 & - & - & 722 \\
Jun. & 161 & 117 & 261 & - & - & 539 \\
Jul. & 78 & 39 & 172 & - & - & 289 \\
Aug. & 12 & 17 & 73 & - & - & 102 \\
\hline
\end{tabular}

The water temperature is one of the most important factor which influences the production of phytoplankton in a river system. Das and Srivastava (1959) pointed out the role of temperature as limiting factor for phytoplanktonic production. Khanna et al. (1993) and Joshi et al. (1996) are of the same view that the planktonic production is mainly influenced by temperature. During the present study, maximum phytoplankton was observed during summers (March and May).

Chlorophyceae was found to be in maximum number in April 2004 and February 2005 when the temperature increased. Abundance of Chlorophyceae genera is usually indicative of a better state 
of water quality. The low incidence of Pediastrum, Cymbella and Spirulina and the dominance of Chlorophyceae indicated the less polluted nature of Mahakali river.

Table 5. Monthly changes in total species number in different groups of phytoplankton in Mahakali river during two years (2003-2005).

\begin{tabular}{lcccccc}
\hline Month & Chloro & Cyano & Bacillario & Dino & Xantho & Total \\
\hline Sep.2003 & 5 & 1 & 1 & - & - & 7 \\
Oct. & 5 & 3 & 1 & 1 & - & 10 \\
Nov. & 5 & 2 & 2 & - & - & 9 \\
Dec. & 4 & 2 & 3 & - & - & 9 \\
Jan.2004 & 5 & 1 & 2 & - & - & 8 \\
Feb. & 3 & 2 & 2 & - & - & 7 \\
Mar. & 3 & 2 & 4 & - & - & 9 \\
Apr. & 5 & 2 & 4 & 1 & - & 12 \\
May & 4 & 4 & 5 & 1 & - & 14 \\
Jun. & 4 & 2 & 3 & - & - & 9 \\
Jul. & 4 & 2 & 3 & - & 1 & 10 \\
Aug. & 5 & 3 & 2 & - & - & 10 \\
Sep. & 6 & 1 & 1 & - & - & 8 \\
Oct. & 4 & 3 & 1 & 1 & - & 9 \\
Nov. & 4 & 2 & 2 & - & - & 8 \\
Dec. & 4 & 2 & 3 & - & - & 9 \\
Jan.2005 & 4 & 1 & 2 & - & - & 7 \\
Feb. & 5 & 2 & 4 & - & - & 11 \\
Mar. & 3 & 2 & 6 & - & - & 11 \\
Apr. & 3 & 1 & 4 & - & - & 8 \\
May & 4 & 1 & 5 & - & - & 10 \\
Jun. & 4 & 3 & 4 & - & - & 11 \\
Jul. & 3 & 2 & 6 & - & - & 11 \\
Aug. & 2 & 2 & 5 & - & - & 9 \\
\hline
\end{tabular}

\section{Acknowledgement}

The author is grateful to the Campus Chief, S.N. Science Campus, Mahendranagar, Kanchanpur, for laboratory facilities and constant encouragements.

\section{References}

Abbas, S.G. 1979. Seasonal variation in the productivity of Macrophytes along the bank of river Ganges. Ph.D. thesis Bhagalpur University, Bhagalpur.

Edmondson, W.T. 1959. Fresh Water Biology. John Wiley and Sons. New York.

Fitter, R. \& R. Manuel. 1986. Freshwater life of Britain and North West Europe. William Collins Sons \& Co. Ltd. London.

George, M.G. 1966. Comparative plankton ecology of five fish tanks in Delhi, India. Hydrobiologia 27(1- 9): 81-108.

Gurung, T.B., R.P. Dhakal \& J.D. Bist. 2006 Phytoplankton primary production, chlorophylla-a and nutrient concentrations in the water column of mountainous Lake Phewa, Nepal. Lakes \& Reservoirs; Research and Management 11: 141-148. http://dx.doi.org/10.1111/j.14401770.2006. 00301.x 
Joshi, B.D., R.C.S. Bisht \& N. Joshi 1996. Him, J. Env. Zool. 10: 31.

Khanna, D.R., S.P. Badola \& A.K. Dobriyal. 1993. Plankton Ecology of the River Ganga at Chandighat, Hardwar. pp. 171-174. In: Advances in Limnology (H.R. Singh Ed.), Narendra Publishing House, Delhi.

Kushwaha P.K. 2012: Bio diversity and density of phytoplankton in pond Kirtipur. Academic Voices 2(1): 43-47.

Mukherjee, B., M. Nivedita, D. Mukherjee. 2010. Plankton diversity and dynamics in a polluted eutrophic lake, Rachi. Journal of Environmental Biology 31: 827-839.

Munawar, M. 1972. Ecological studies of Euglenineae in certain polluted and unpolluted environments. Hydrobiologia 39(3): 307-320. http://dx.doi.org/10.1007/BF00046647

Murugesan, V.K., R. Palaniswami \& S. Manobaran. 2003. Productivity of reservoirs in Tamil Nadu with reference to their plankton population. J. Inland Fish. Soc. India 35(2): 50-56.

Sarkar, H.K. \& H. Rai. 1964. The limnology of the Suraj Kund, India. Physico-chemical conditions and plankton. Trans. Amer. Micro. Soc. 83: 260-266. http://dx.doi.org/10.2307/3224576

Sehgal, K.L. 1992. Impact of construction and completion of Beas-Sutlej Link (BSL) Project on Coldwater Fisheries of R. Beas in Himachal Pradesh. In: Recent Researches in Coldwater Fisheries (K.L. Sehgal Ed.), Today and Tomorrow's Printers and Publishers, New Delhi, 1670.

Senthilkumar, R. \& K. Sivakumar. 2008. Studies on phytoplankton diversity in response to abiotic factors in Veeranam lake in the Cuddalore district of TamilNadu. Journal of Environmental Biology 29(5): 747-752.

Sharma, A.P., S. Jaiswal, V. Negi \& M.C. Pant. 1982. Phytoplankton community analysis in lakes of Kumaun Himalay. Arch. Hydrobiol. 93: 173-193.

Sharma, R.C. 1991. Rhithronology of Bhagirathi, Garhwal Himalaya (India). In: Ecology of the Mountain Waters. (S.D. Bhatt \& R.K. Pande Eds.), Ashish Publ. House, New Delhi, 125137.

Shrivastava, N.P. 2005. Plankton status of Ravishankar Sagar reservoir. J. Inland Fish. Soc. India 37(2): 43-47.

Singh, D.K. \& I. Singh. 2008. Interrelationship of certain physic-chemical parameters with plankton community of Motipur Ox-bow lakes (Muzaffarpur, Bihar). Environment \& Ecology 26(2): 800-803.

Singh, V.K. \& A.P. Sharma. 1998. Community structure of plankton in Fish ponds manured with three organic manures. Him. J. Env. Zool. 12: 91-98.

Srivastava, K. \& S. Prakash. 2003. Spatio-temporal variation on phytoplankton in river Mahanadi. $J$. Inland Fish. Soc. India 35(1): 53-57.

Srivastava, V.K. \& S.R. Singh. 1995. Seasonal dynamics of zooplankton in Ganga river (between Buxar and Ballia) in relation to water quality. Proc. Acad. Environ. Biol. 4(1): 83-89.

Tiwari, A. \& S.V.Chauhaan. 2006. Seasonal phytoplanktonic diversity of Kitham lake, Agra. Journal of Environmental Biology 27: 35-38.

Tiwati, D. \& M. Shukla. 2007. Algal biodiversity and trophic status of some temporary water bodies of Kanpur. Nat. Environ. Pollut. Technol. 6: 85-90.

Veereshkumar, N.S. \& S.P. Homani. 2006. Algal biodiversity in freshwatwe and related to physicochemecal factors. Nat. Environ. Pollut. Technol. 5: 37-40. 